\title{
Temperatures Outside the Optimal Range for Helicobacter pylori Increase Its Harboring within Candida Yeast Cells
}

\author{
Kimberly Sánchez-Alonzo ${ }^{1}$, Luciano Arellano-Arriagada ${ }^{1}$, Susana Castro-Seriche ${ }^{1}{ }^{1}$, \\ Cristian Parra-Sepúlveda ${ }^{1}{ }^{(0)}$, Humberto Bernasconi ${ }^{2}$, Héctor Benavidez-Hernández ${ }^{1}$, Víctor L. Campos ${ }^{3}$, \\ Katia Sáez ${ }^{4}$, Carlos T. Smith ${ }^{1}$ (1) and Apolinaria García-Cancino ${ }^{1, * \mathbb{B}}$
}

1 Laboratory of Bacterial Pathogenicity, Department of Microbiology, Faculty of Biological Sciences, Universidad de Concepcion, Concepción 4070386, Chile; kimsanchez@udec.cl (K.S.-A.); lucarellano@udec.cl (L.A.-A.); sucastro@udec.cl (S.C.-S.); cparras@udec.cl (C.P.-S.); hebenavides@udec.cl (H.B.-H.); csmith@udec.cl (C.T.S.)

2 Laboratorio Pasteur, Research and Development Area, Concepción 4030000, Chile; hbernasconi@lpasteur.cl

3 Laboratory of Environmental Microbiology, Department of Microbiology, Faculty of Biological Sciences, Universidad de Concepción, Concepción 4070386, Chile; vcampos@udec.cl

4 Department of Statistics, Faculty of Physical and Mathematical Sciences, Universidad de Concepción, Concepción 4070386, Chile; ksaez@udec.cl

check for updates

Citation: Sánchez-Alonzo, K.; Arellano-Arriagada, L.;

Castro-Seriche, S.; Parra-Sepúlveda,

C.; Bernasconi, H.;

Benavidez-Hernández, H.; Campos,

V.L.; Sáez, K.; Smith, C.T.;

García-Cancino, A. Temperatures

Outside the Optimal Range for

Helicobacter pylori Increase Its

Harboring within Candida Yeast Cells.

Biology 2021, 10, 915. https://

doi.org/10.3390/biology10090915

Academic Editor: Maikel

P. Peppelenbosch

Received: 27 July 2021

Accepted: 7 September 2021

Published: 15 September 2021

Publisher's Note: MDPI stays neutral with regard to jurisdictional claims in published maps and institutional affiliations.

Copyright: (c) 2021 by the authors. Licensee MDPI, Basel, Switzerland. This article is an open access article distributed under the terms and conditions of the Creative Commons Attribution (CC BY) license (https:// creativecommons.org/licenses/by/ $4.0 /)$.
* Correspondence: apgarcia@udec.cl; Tel.: +56-41-2204144; Fax: 56-41-2245975

Simple Summary: Helicobacter pylori is associated with the development of diverse gastric pathologies. This bacterium has been shown to invade yeast to protect itself from environmental factors such as changes in $\mathrm{pH}$, the presence of antibiotics or variations in nutrients that affect their viability. However, intra-yeast $H$. pylori has been reported from other sources, including food, or when the storage temperature is outside the optimal growth range for $H$. pylori, which is $30-37^{\circ} \mathrm{C}$. It is necessary to continue investigating the environmental factors that participate in the entry of the bacteria into yeast. In this work, it was evaluated whether temperature changes promote the entry of $H$. pylori into Candida and whether this endosymbiosis favors bacterial viability. It was observed that H. pylori significantly increased its invasiveness to yeast when these two microorganisms were co-cultured under $40{ }^{\circ} \mathrm{C}$. The results support that $H$. pylori invades yeasts to protect itself from stressful environments, favoring its viability in these environments. In addition, it can be suggested that this microorganism would use yeast as a transmission vehicle, thereby contributing to its dissemination in the population. However, the latter still needs to be confirmed.

Abstract: Helicobacter pylori is capable of entering into yeast, but the factors driving this endosymbiosis remain unknown. This work aimed to determine if temperatures outside the optimal range for H. pylori increase its harboring within Candida. H. pylori strains were co-cultured with Candida strains in Brucella broth supplemented with $5 \%$ fetal bovine serum and incubated at $4,25,37$ or $40{ }^{\circ} \mathrm{C}$. After co-culturing, yeasts containing bacteria-like bodies (Y-BLBs) were observed by optical microscopy, and the bacterium were identified as $H$. pylori by FISH. The H. pylori $16 S$ rRNA gene was amplified from the total DNA of Y-BLBs. The viability of intra-yeast $H$. pylori cells was confirmed using a viability assay. All H. pylori strains were capable of entering into all Candida strains assayed. The higher percentages of Y-BLBs are obtained at $40{ }^{\circ} \mathrm{C}$ with any of the Candida strains. H pylori also increased its harboring within yeast in co-cultures incubated at $25^{\circ} \mathrm{C}$ when compared to those incubated at $37^{\circ} \mathrm{C}$. In conclusion, although $\mathrm{H}$. pylori grew significantly at $40^{\circ} \mathrm{C}$, this temperature increased its harboring within Candida. The endosymbiosis between both microorganisms is strain-dependent and permits bacterial cells to remain viable under the stressing environmental conditions assayed.

Keywords: Helicobacter pylori; intracellular; Candida; stress; temperature 


\section{Introduction}

Helicobacter pylori is a Gram-negative, microaerophilic bacterium whose optimum growth temperature is in the range of $35-37^{\circ} \mathrm{C}$ [1]. This pathogen colonizes the human stomach [2]. Moreover, it has been detected, by molecular techniques, in diverse water sources and food (including milk and fruits). Nevertheless, reports of the isolation of this pathogen by culture techniques from the same sources previously mentioned are scarce [3-6]. For example, it has been reported that this bacterium can remain viable for 9-11 days in vitro $H$. pylori-contaminated milk [4], possibly because it acquires a viable but not culturable (VBNC) condition when it is subjected to stressing factors, such as changes of temperature, $\mathrm{pH}$ or exposure to oxygen, making it difficult to isolate it in culture media $[7,8]$. Several environmental factors affect microbial growth rate, the temperature being among the key ones. Therefore, temperature variations can be considered as one of the main stressing factors to which microorganisms are subjected. Temperature affects, among others, the fluidity and function of the cell membrane, gene expression, enzymatic activity and transport of nutrients. Thus, adaptation to temperature is crucial for microorganisms to remain viable [9-11], with H. pylori, the bacterium subject of the present work, not being an exception.

H. pylori is a microorganism showing a high worldwide prevalence, ranging from 85 to $95 \%$ in developing countries and $30-50 \%$ in developed countries [12-14]. These are alarming percentages considering all the gastric and extra-gastric pathologies associated with the infection with this pathogen $[15,16]$ and its increased antibiotic resistance $[17,18]$. Moreover, in 2017, H. pylori were included by the WHO in the list of priority pathogens resistant to antibiotics, and it was classified as priority 2: high [19]. The last Maastricht consensus established that in case of the presence of H. pylori in a patient, even in asymptomatic cases, the microorganism must be eradicated in order to reduce the incidence of the pathologies associated with this bacterium [20].

Although H. pylori has been studied for more than 35 years [21], still, several questions remain regarding its dissemination, protection and evasion to treatments against its infection mechanisms [22,23]. This is related to several survival mechanisms, among them its ecological niche, the gastric environment, which considerably reduces the action of antibiotics that scarcely diffuse in the mucosa covering this anatomical site and the inactivation of these compounds due to the stomach $\mathrm{pH}$ [24]. Additionally, this microorganism is capable of developing a coccoid stage, a resistance strategy, or forming biofilms; both conditions allow its survival in stressing environments, such as the presence of antibiotics, deficiency of nutrients or acidic $\mathrm{pH}[8,24-27]$. In addition, $H$. pylori has the ability to harbor within eukaryotic cells when subjected to stressing conditions [27-31], a mechanism making harder its eradication and also favoring its dissemination. In this sense, H. pylori may remain viable within free-living amoebas isolated from water sources [32-34]. Another microorganism postulated as a possible shelter and transmission vehicle for H. pylori are yeasts, which are present both in humans and food [6,35-38]. Yeasts are capable of adapting to different environmental conditions, such as deficiency of nutrients or $\mathrm{pH}$ and temperature fluctuations [39]. With respect to yeasts belonging to the genus Candida, considered as opportunistic pathogens, it is known that they successfully colonize the human body and that they are part of the normal mouth, skin and genitals microbiota of some healthy individuals [40-42]. They can grow under various environmental conditions, including a wide range of temperatures $\left(20-42{ }^{\circ} \mathrm{C}\right)$ [43], which might protect intra-yeast $H$. pylori cells from changes in this environmental factor.

The literature has provided evidence of a close relationship between $H$. pylori and yeast cells belonging to the genus Candida. Ansorg and coworkers provided, in 1998, one of the earliest reports on this relationship [44]. The presence of these two microorganisms in gastric ulcers triggers a severe manifestation of this pathology $[45,46]$, suggesting that the interaction between these two microorganisms may be more relevant than that so far recognized. Nevertheless, despite the importance of the relationship between intra-yeast H. pylori and Candida, there is still a significant lack of knowledge on this relationship which 
is required to be investigated. Considering the particular interest of our research group to investigate the environmental factors which may promote the internalization of this pathogenic bacterium within yeasts [47-49], the aim of the present work was to determine if temperatures outside the optimal growth rate of $H$. pylori promote its internalization into yeasts of the genus Candida and to determine if the temperature-triggered bacterium yeast endosymbiotic relationship is strain-dependent.

\section{Materials and Methods}

\subsection{Strains}

In this work, $H$. pylori and Candida strains were used. Regarding H. pylori, the strains used were SS-1, G-27, ATCC 700824 (often referred to as J99) and H707. The first three are $H$. pylori reference strains, and the latter was obtained from a gastric biopsy. With respect to Candida, two reference strains C. glabrata ATCC 90030 and C. albicans ATCC 90028, and two clinical strains, obtained from a vaginal flow (C. albicans VT-3) and from the oral cavity (C. glabrata LEO-37), were used. All these strains are maintained at the Laboratory of Bacterial Pathogenicity, Department of Microbiology, Faculty of Biological Sciences, University of Concepcion, Chile.

\subsection{Strains Culture}

H. pylori was cultured in Columbia agar (CA) (OXOID, Basingstoke, UK) supplemented with $5 \%$ fetal bovine serum (FBS) (Biological Industries, Cromwell, CT, USA) and incubated under microaerobic conditions (Thermo Scientific, Waltham, MA, USA) at $37^{\circ} \mathrm{C}$ for 48-72 h. Candida strains were cultured in Sabouraud agar (SA) (Merck, Darmstadt, Germany) supplemented with chloramphenicol (CHL) (OXOID, Basingstoke, United Kingdom) following the instructions of the manufacturer. Yeast cultures were incubated under aerobic conditions (ZHICHENG, Shanghai, China) at $37^{\circ} \mathrm{C}$ for $24 \mathrm{~h}$. The purity of the H. pylori cultures was checked by Gram-staining and urease, catalase and oxidase tests. The purity of the Candida strains was checked by Gram staining, reseeding in CHROMagar (Difco, Wokingham, UK) and the urease test.

\subsection{Growth Curves of H. pylori and Candida Strains at $4{ }^{\circ} \mathrm{C}, 25^{\circ} \mathrm{C}, 37^{\circ} \mathrm{C}$ or $40^{\circ} \mathrm{C}$}

In order to make sure to start the co-cultures of $\mathrm{H}$. pylori and Candida strains when both microorganisms were in their respective exponential phase of growth, this assay was necessary to determine the incubation time required by each microorganism to reach the desired phase of growth. Each strain of either H. pylori or Candida spp. used in the present work was suspended at an optical density (OD) of 0.1 at $600 \mathrm{~nm}$ in Brucella broth (BB) (Difco, Wokingham, UK) supplemented with 5\% FBS (BB-5\%FBS), and $200 \mu \mathrm{L}$ of each suspension were placed in a well of 96-well plates (Thomas Scientific, Swedesboro, NJ, USA) and plates incubated at $4{ }^{\circ} \mathrm{C}, 25^{\circ} \mathrm{C}, 37^{\circ} \mathrm{C}$ or $40^{\circ} \mathrm{C}$ in an Infinite M200 PRO equipment (TECAN, Männedorf, Switzerland), in which the microaerobic conditions were obtained using CampyGen envelopes (Thermo Scientific, Waltham, MA, USA). The growth of each strain was monitored by OD at $600 \mathrm{~nm}$ every $8 \mathrm{~h}$ during $72 \mathrm{~h}$ for the bacterial strains and every $2 \mathrm{~h}$ during $50 \mathrm{~h}$ in the case of yeast strains. Additionally, in the case of H. pylori, $5 \mu \mathrm{L}$ aliquots were obtained at each time OD was measured, and a Gram-staining was prepared to monitor possible morphological changes in bacterial cells caused by the incubation conditions.

\subsection{Co-Cultures of H. pylori Strains with C. albicans Strains}

Each H. pylori strain was co-cultured with each Candida spp. strain. A suspension of each strain of each kind of microorganism was independently prepared in $0.89 \%$ saline solution (SS) and adjusted to an OD of 0.1 at $600 \mathrm{~nm}$. Then, $500 \mu \mathrm{L}$ of each suspension of the bacterial strains were placed in wells of 12-well plates (Thomas Scientific, Swedesboro, NJ, USA) previously loaded with $4 \mathrm{~mL}$ de BB-5\%FBS. Then, $500 \mu \mathrm{L}$ of yeast cells from each strain were independently added to wells previously inoculated with $H$. pylori. Four 
wells were required for each bacterial strain in order to be independently co-cultured with each of the yeast strains. Plates containing the co-cultures were incubated under microaerobic conditions for $48 \mathrm{~h}$ at the following temperatures: $4{ }^{\circ} \mathrm{C}, 20^{\circ} \mathrm{C}, 37^{\circ} \mathrm{C}$ or $40^{\circ} \mathrm{C}$. Microaerobiosis atmosphere was achieved using CampyGen envelopes (Thermo Scientific, Waltham, MA, USA). All assays were repeated thrice. As controls for this assay, pure inocula of all H. pylori and Candida strains were used.

\subsection{Search for Yeast Cells Containing Bacteria-Like Bodies (Y-BLBs)}

During the $48 \mathrm{~h}$ incubation of the co-cultures, a $20 \mu \mathrm{L}$ aliquot of each of them was obtained at times $0,1,3,6,12,24$ and $48 \mathrm{~h}$ and placed on a glass slide to prepare wet mounts for observation under an optical microscope, using the oil immersion $100 \times$ objective lens, (Leica, Wetzlar, Germany fitted with camera). For each co-culture, 200 yeast cells were counted and the percentage of yeast cells containing mobile bacteria-like bodies (Y-BLBs) was calculated. Additionally, to be used in the following assays, a sample from the co-cultures was added to $1 \mathrm{~mL}$ BB-5\%FBS, vortexed (DLAB, Ontario, CA, USA) and $0.015 \mu \mathrm{g} / \mathrm{mL}$ clarithromycin (Sigma-Aldrich, St. Louis, MO, USA) added. This mixture was incubated under microaerobic conditions at $37^{\circ} \mathrm{C}$ for $24 \mathrm{~h}$ to eliminate extracellular remaining $H$. pylori cells. Then, $20 \mu \mathrm{L}$ of the culture were seeded on the surface of dishes containing Sabouraud agar (Merck, Darmstadt, Germany) plus $50 \mathrm{mg} / \mathrm{L}$ chloramphenicol (OXOID, Basingstoke, UK) (SA-CHL) and incubated for further $24 \mathrm{~h}$ at $37^{\circ} \mathrm{C}$ under microaerobic conditions and colonies reseeded 6 times in SA-CHL to eliminate any residual extracellular H. pylori cells.

\subsection{Identification of Intra-Yeast BLBs as H. pylori Using the FISH Technique}

This procedure was completed according to Sánchez-Alonzo and coworkers [48] with modifications. Yeast cells previously co-cultured with H. pylori and showing BLBs were incubated at $37^{\circ} \mathrm{C}$ for $24 \mathrm{~h}$ in SA-CHL to obtain yeast colonies free of extracellular bacteria. Cells from randomly selected colonies were transferred to tubes containing $1 \mathrm{~mL} 1 \mathrm{X}$ sterile phosphate-buffered saline (PBS) (Sigma-Aldrich, St. Louis, MO, USA) until reaching turbidity similar to tube 3 of the McFarland scale. Tubes were centrifuged at $6700 \times g$ for 2 min (Eppendorf, San Diego, CA, USA), washed once under the same conditions, the supernatant was discarded and $1 \mathrm{~mL} 1 \mathrm{X}$ PBS added to the pellet. The pellet was resuspended using a vortex (DLAB, Ontario, CA, USA) at medium speed for $10 \mathrm{~s}$ and $100 \mu \mathrm{L}$ aliquots of each suspension placed on a glass slide. Smears were dried at room temperature for approximately $20 \mathrm{~min}$ and fixed using $200 \mu \mathrm{L}$ formaldehyde solution (37\%) (Sigma-Aldrich, St. Louis, MO, USA) and allowed to rest for $3 \mathrm{~h}$ at $4{ }^{\circ} \mathrm{C}$ in a humid chamber. Fixative was discarded and smears dehydrated with $1 \mathrm{~mL}$ of $50 \%, 80 \%$ and $96 \%$ ethanol (3 min each) and allowed to dry at room temperature. Then, $100 \mu \mathrm{L}$ hybridization solution $(270 \mu \mathrm{L} \mathrm{NaCl} 5 \mathrm{M}, 30 \mu \mathrm{L}$ TRIS-HCl $1 \mathrm{M} ; 525 \mu \mathrm{L}$ deionized formamide $37.7 \%, 675 \mu \mathrm{L}$ MiliQ water and $1.5 \mu \mathrm{L}$ SDS 10\%) and $6 \mu \mathrm{L}$ Hpy probe $5^{\prime}$-CACACCTGACTGACTATCCCG-3' labeled with $\mathrm{Cy} 3$ [50] at a $5 \mathrm{ng} \mu \mathrm{L}^{-1}$ concentration were added to each smear. Slides were incubated in a thermoregulated bath (Elma, Singen, Germany) at $46-48{ }^{\circ} \mathrm{C}$ for $90 \mathrm{~min}$ in darkness and then $1 \mathrm{~mL}$ of preheated $\left(46-48{ }^{\circ} \mathrm{C}\right)$ washing buffer $(700 \mu \mathrm{L} \mathrm{NaCl} 5 \mathrm{M}$, $1 \mathrm{~mL} 1 \mathrm{M}$ TRIS-HCl, $48.25 \mathrm{~mL}$ sterile distilled water and $50 \mu \mathrm{L}$ SDS 10\%) were added and incubated at the same temperature for further $20 \mathrm{~min}$. After this time span, washing was repeated under the same conditions but incubated for only $5 \mathrm{~min}$, and slides were allowed to dry at room temperature in the darkness. Once dried, $100 \mu \mathrm{L}$ ConA-FITC $1 \mathrm{mg} \mathrm{mL}^{-1}$ (Sigma-Aldrich, St. Louis, MO, USA) was added to each smear and incubated for $10 \mathrm{~min}$ at room temperature in darkness, washed twice using $1 \mathrm{~mL} 1 \mathrm{X}$ PBS and allowed to dry in the darkness. Smears were observed using a fluorescence microscope fitted with a camera and filters FITC (AT480/535) and TRIC (AT540/605) (Motic, Viking Way, Richmond, VA, Canada). Images were processed and merged using the ImageJ software (NIH Image, Bethesda, MD, USA). For this assay, pure cultures of H. pylori H707 and C. glabrata LEO-37 were used as positive control and negative control, respectively. 


\subsection{Detection of the H. pylori $16 S$ rRNA Gene in Total DNA Extracted from Y-BLBs}

Y-BLBs were obtained as described above (FISH assay). Total DNA of yeast cells was obtained by means of the UltraClean Microbial DNA Isolation kit (MO BIO, Carlsbad, CA, USA), following the instructions of the manufacturer. To amplify the H. pylori $16 S$ rRNA gene, $0.2 \mathrm{~mL}$ Eppendorf tubes (Eppendorf, Framingham, MA, USA) were loaded with $12.5 \mu \mathrm{L}$ master mix (TAKARA BIO INC, Shiga, Japan), $1 \mu \mathrm{L}$ specific primers F-5'CTCGAGAGACTAAGCCCTCC $3^{\prime}$ and R-5' ATCTGACGCTGATGTGC $3^{\prime}$ [11], $1.5 \mu \mathrm{L}$ yeast DNA and 5.5 $\mu \mathrm{L}$ PCR grade water to obtain a final volume of $25 \mu \mathrm{L}$. An Eppendorf thermocycler (Eppendorf, Framingham, MA, USA) was programmed for 30 PCR amplification cycles using an initial denaturation temperature of $94{ }^{\circ} \mathrm{C}$ for $1 \mathrm{~min}$, denaturation temperature of $98^{\circ} \mathrm{C}$ for $30 \mathrm{~s}$, hybridization temperature of $53^{\circ} \mathrm{C}$ for $5 \mathrm{~s}$ and extension temperature of $72{ }^{\circ} \mathrm{C}$ for $40 \mathrm{~s}$ and a final extension temperature of $72{ }^{\circ} \mathrm{C}$ for $10 \mathrm{~min}$. Then, electrophoresis was performed in a $2 \%$ agarose gel (Lonza, Walkersville, MD, USA) plus $1 \mu \mathrm{L}$ GelRed (Biotium, Fremont, CA, USA) at $70 \mathrm{~V}$ for $90 \mathrm{~min}$. Amplicons were observed under UV light using an ENDURO photo documentation system (Labnet, Edison, NJ, USA). As control for this assay, DNA from H. pylori SS-1 was used as positive control and DNA from C. albicans ATCC 90028 as negative control.

\subsection{Cell Viability Assay}

In $24 \mathrm{~h}$ cultures in SA of yeasts which were positive for the presence of BLBs after being co-cultured for $48 \mathrm{~h}$ with $H$. pylori, yeast colonies were randomly selected, suspended in $1 \mathrm{~mL}$ of SS and adjusted to turbidity similar to 0.5 of the McFarland scale. Then, $1 \mu \mathrm{L}$ working solution of the LIVE/DEAD BacLight Bacterial Viability Kit L-7012 (ThermoFisher, USA) was added, and the suspension was incubated for $15 \mathrm{~min}$ in the darkness. Then, suspensions were vortexed (DLAB, Ontario, CA, USA) at minimal speed for $3 \mathrm{~s}$. Posteriorly, $10 \mu \mathrm{L}$ of the suspension was placed on a glass slide and observed using the $100 \times$ objective lens of a fluorescence microscope fitted with a camera (Motic, Viking Way, Richmond, VA, Canada). The filters used were FITC (AT480/535) and TRIC (AT540/605). Images were processed using the ImageJ (NIH Image, USA) software for merging them.

\subsection{Statistical Analysis}

SPSS 24.0 software (IBM Company, Armonk, NY, USA) was used to process the data obtained. Tukey's test was applied to determine the presence of statistically significant differences. Values of $p \leq 0.05$ were considered significant, and values of $p \leq 0.0001$ were considered highly significant. According to the results of Tukey's test, data shown in tables or figures sharing the same letter are not significantly different.

\section{Results}

\subsection{Growth Curves of H. pylori and Candida Strains at Different Temperatures}

In order to start the H. pylori-Candida co-cultures with both microorganisms in their exponential phase, it was necessary, as a first step, to determine the growth curves of the four H. pylori and of the four Candida strains. The growth curves of the H. pylori strains (J99, SS-1, G-27 and H707) cultured at $4{ }^{\circ} \mathrm{C}, 25^{\circ} \mathrm{C}, 37^{\circ} \mathrm{C}$ or $40^{\circ} \mathrm{C}$ showed that the strains only grew when incubated at $37^{\circ} \mathrm{C}$ or $40^{\circ} \mathrm{C}$ (Figure 1). There were significant differences when the growth at the two higher temperatures was compared to that of the two lower temperatures. All four strains showed no significant difference when incubated at $37^{\circ} \mathrm{C}$ or $40^{\circ} \mathrm{C}(p=0.07)$. Nevertheless, the exponential phase started earlier when incubated at $37^{\circ} \mathrm{C}(8 \mathrm{~h})$ than at $40^{\circ} \mathrm{C}(16 \mathrm{~h})$. On the other hand, Gram staining showed a larger number of coccoid $\mathrm{H}$. pylori cells when incubated at $40{ }^{\circ} \mathrm{C}$ compared to the incubation at $37^{\circ} \mathrm{C}$ (Figure S1). 
$\mathbf{A}$

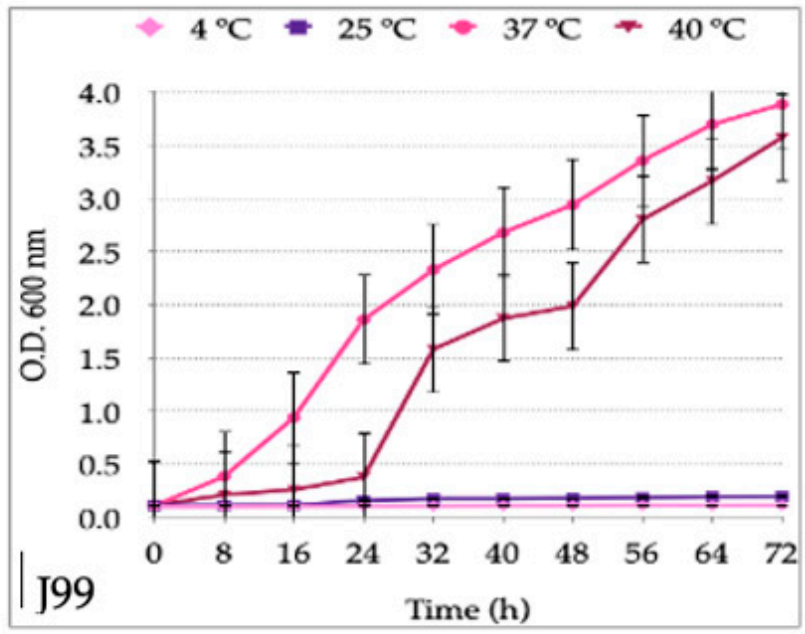

C

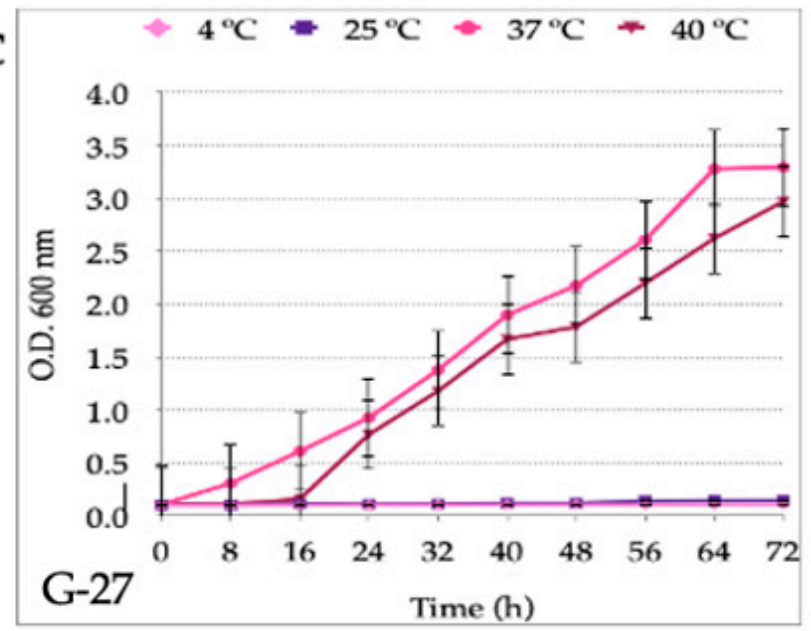

B

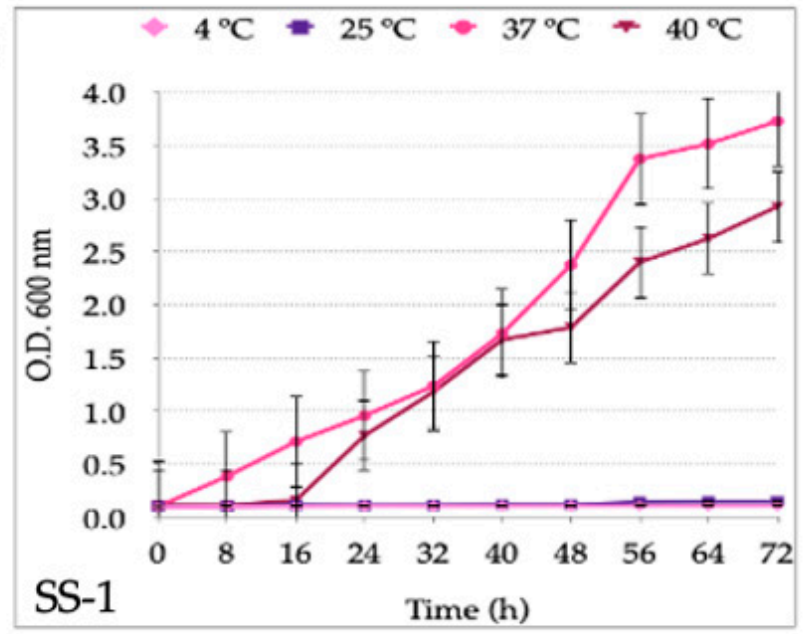

D

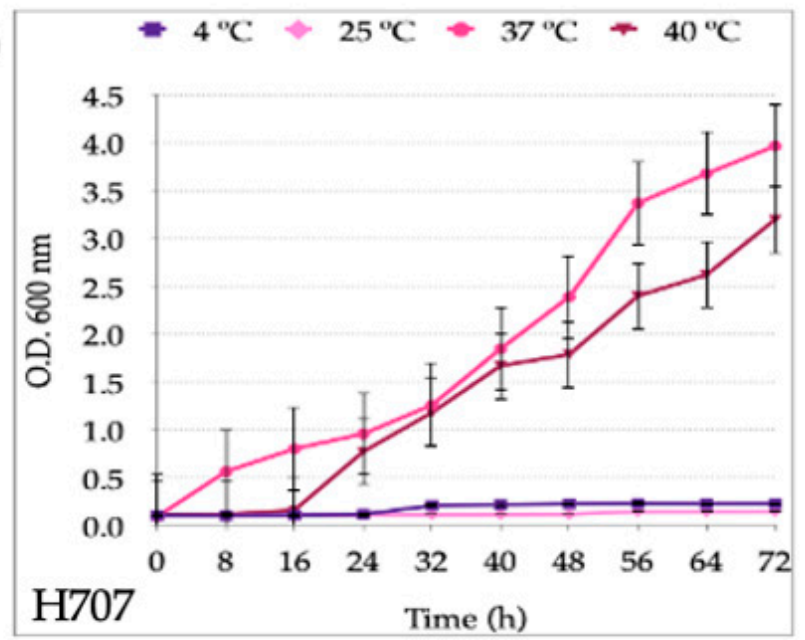

Figure 1. Growth curves of H. pylori strains (A) J99, (B) SS-1, (C) G-27 and (D) H707 incubated at $4{ }^{\circ} \mathrm{C}, 25^{\circ} \mathrm{C}, 37^{\circ} \mathrm{C}$ or $40{ }^{\circ} \mathrm{C}$ in Brucella broth supplemented with $5 \%$ bovine serum. Results are expressed as mean \pm SD. OD: optical density.

Regarding the growth curves of the Candida strains, all four of them (C. albicans ATCC 90028, C. glabrata ATCC 90030, C. albicans of vaginal origin VT-3 and C. glabrata of oral origin LEO-37) grew when incubated at $25^{\circ} \mathrm{C}, 37^{\circ} \mathrm{C}$ or $40{ }^{\circ} \mathrm{C}$, showing no significant differences at these three temperatures. When incubated at $4{ }^{\circ} \mathrm{C}$, all four Candida strains showed a short exponential growth phase and an extended stationary phase starting at $18 \mathrm{~h}$ of incubation (Figure 2). No significant differences were observed when comparing the growth of each yeast strain at $37^{\circ} \mathrm{C}$ and $40^{\circ} \mathrm{C}(p=1.9)$ or at $40^{\circ} \mathrm{C}$ and $25^{\circ} \mathrm{C}(p=1.0)$. When comparing the growth curves obtained at $25^{\circ} \mathrm{C}$ with those obtained at $37^{\circ} \mathrm{C}$, no significant difference was observed. A significant decrease was observed when the growth at $4{ }^{\circ} \mathrm{C}$ was compared to that at $25^{\circ} \mathrm{C}, 37^{\circ} \mathrm{C}$ or $40{ }^{\circ} \mathrm{C}(p=0.009)$. 


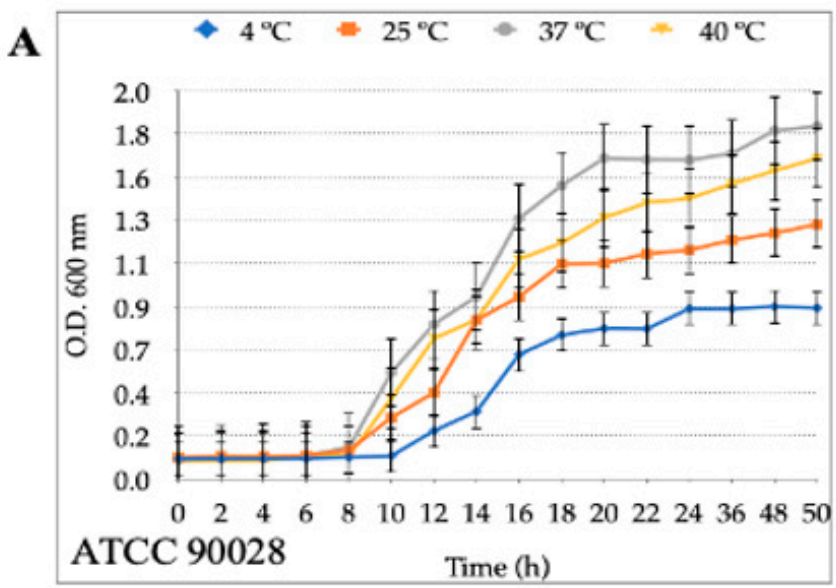

B
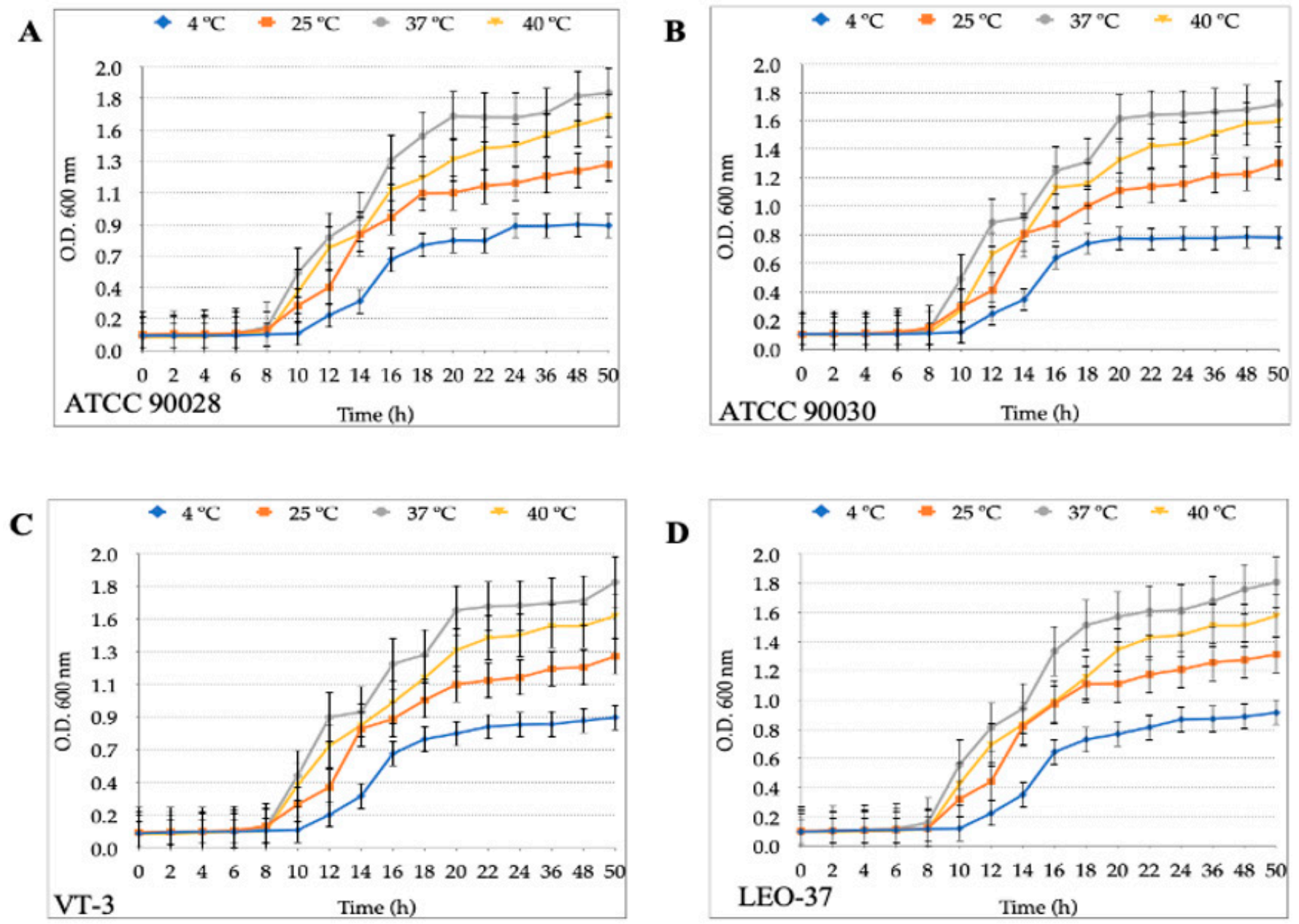

Figure 2. Growth curves of the four strains of Candida assayed: (A) C. albicans ATCC 90028 (B) C. glabrata ATCC 90030 , (C) C. albicans of vaginal origin VT-3 and (D) C. glabrata of oral origin LEO-37 cultured at $4{ }^{\circ} \mathrm{C}, 25^{\circ} \mathrm{C}, 37^{\circ} \mathrm{C}$ or $40{ }^{\circ} \mathrm{C}$ in Brucella broth supplemented with $5 \%$ fetal bovine serum. Results are expressed as mean \pm SD. OD: optical density.

\subsection{Identification of Bacteria-Like Bodies (BLBs) within Yeast Cells after Co-Culturing Both Microorganisms at Different Temperatures}

The observation of fresh mounts of aliquots obtained from $\mathrm{H}$. pylori and Candida strains co-cultures incubated at $4{ }^{\circ} \mathrm{C}, 25^{\circ} \mathrm{C}, 37^{\circ} \mathrm{C}$ or $40^{\circ} \mathrm{C}$ for $48 \mathrm{~h}$ allowed detecting the presence of Y-BLBs (Figure 3). The mean of Y-BLBs percentages obtained when co-incubating $H$. pylori strains with Candida strains was calculated considering the global number of Y-BLBs per incubation temperature and the H. pylori strain being evaluated. The quantification of Y-BLBs indicated that the larger Y-BLBs percentage was present in co-cultures incubated at $40{ }^{\circ} \mathrm{C}(46$ to $57 \%)$ followed by those incubated at $25^{\circ} \mathrm{C}(22$ to $27 \%), 37^{\circ} \mathrm{C}(10$ to $21 \%)$ and finally those at $4{ }^{\circ} \mathrm{C}$ (8 to $11 \%$ ) (Figure 4$)$. It was also observed that co-cultures combining the H. pylori $\mathrm{J} 99$ strain with all Candida strains incubated at $25^{\circ} \mathrm{C}$ and $40{ }^{\circ} \mathrm{C}$ showed the largest percentages of Y-BLBs, but not at the rest of the temperatures assayed (Figure 4). The wet mounts of co-cultures also showed H. pylori cells adhered to hyphae of yeasts (a Gram staining demonstrating this observation is shown in Figure S2). 

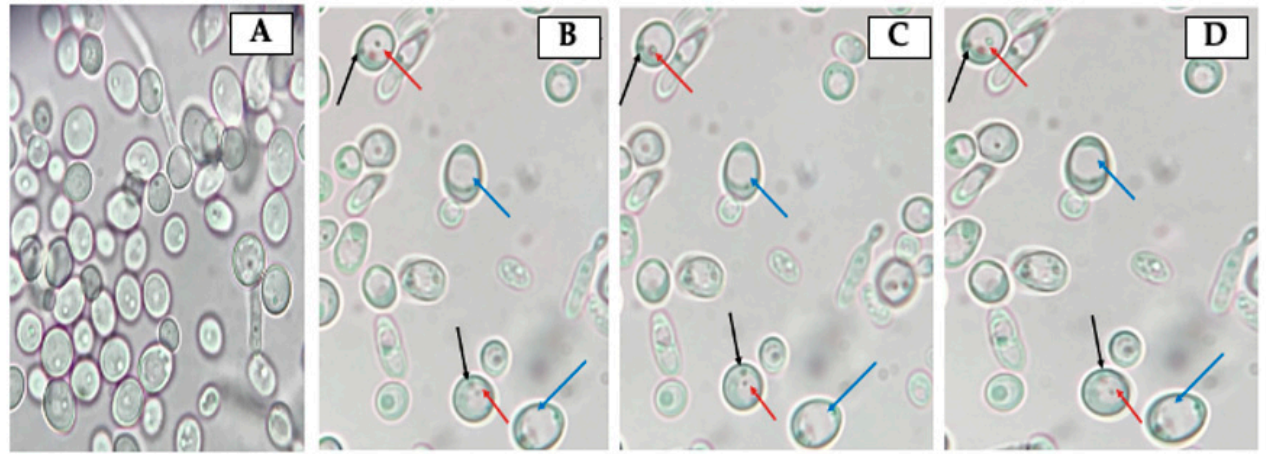

Figure 3. Micrographs, obtained at $1 \mathrm{~s}$ intervals, of wet mounts from (A) pure culture of C. albicans VT-3 (yeast purity control), (B-D) H. pylori G-27 and C. albicans VT-3 co-cultures incubated at $37{ }^{\circ} \mathrm{C}$, showing the change in position of bacteria-like bodies (BLBs) (red arrows). Additionally, it is possible to observe yeast cells lacking BLBs (blue arrows) and nuclei of yeast cells (black arrows). The movement of BLBs can be observed in Video S1.

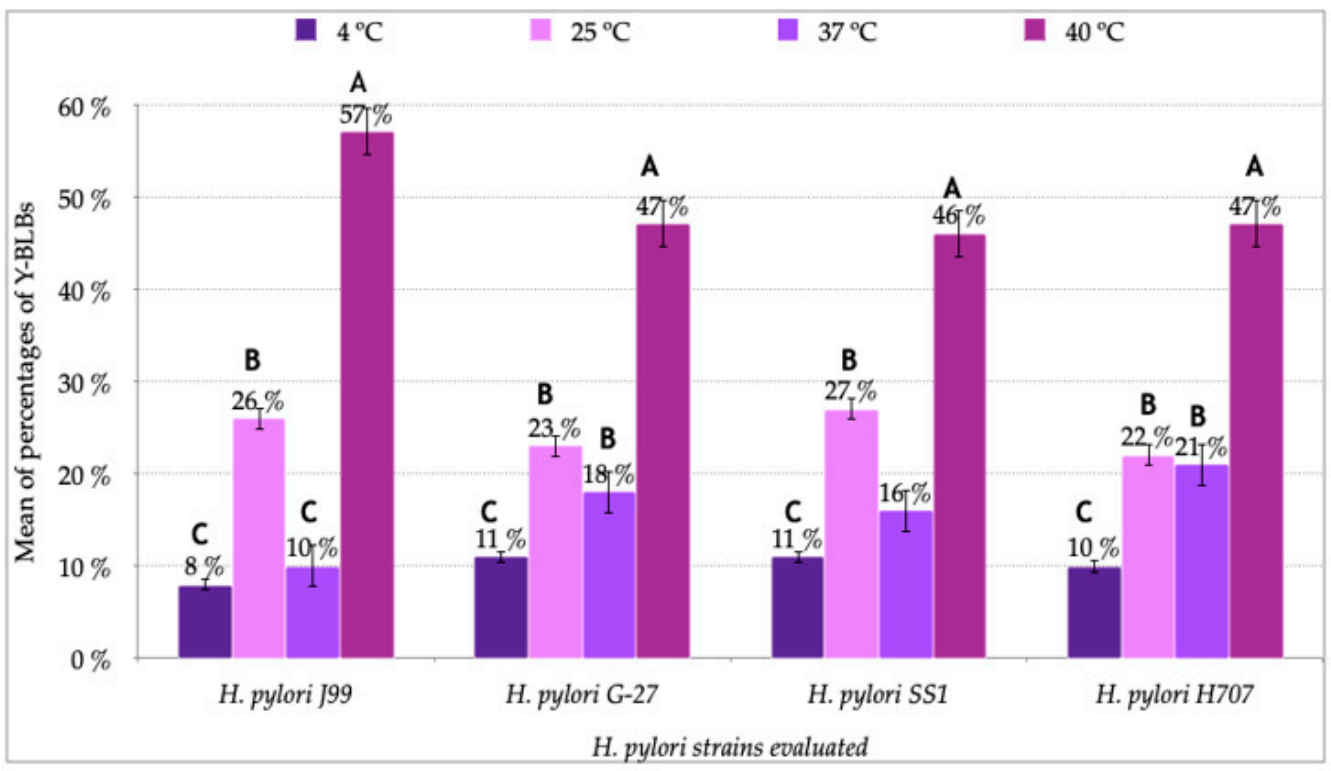

Figure 4. Average of the mean percentages of yeasts cells harboring bacteria-like bodies (Y-BLBs) of the four Candida strains after co-incubation of $H$. pylori strains with Candida strains at $4{ }^{\circ} \mathrm{C}, 25{ }^{\circ} \mathrm{C}$, $37^{\circ} \mathrm{C}$ or $40^{\circ} \mathrm{C}$ during $48 \mathrm{~h}$. The highest percentage of BLBs was found in co-cultures incubated at $40^{\circ} \mathrm{C}$. It can be seen that the highest percentages were obtained with the co-cultures carried out with the H. pylori $\mathrm{J} 99$ strain in microaerobic conditions. Results are expressed as mean $\pm \mathrm{SD}$. Means with different letters are significantly different $(p<0.05)$.

In the co-cultures incubated at $4{ }^{\circ} \mathrm{C}, 25^{\circ} \mathrm{C}$ or $40{ }^{\circ} \mathrm{C}$, Y-BLBs were observed from the first hour of co-culture, but in the co-cultures incubated at $37^{\circ} \mathrm{C}$, Y-BLBs were observed after $3 \mathrm{~h}$ of co-culture. The averages of the mean Y-BLBs calculated after incubating the co-cultures at $4{ }^{\circ} \mathrm{C}$ or $25^{\circ} \mathrm{C}$ were lower than those obtained when incubating at $37^{\circ} \mathrm{C}$ or $40^{\circ} \mathrm{C}$ (Figure 5). Figure 5 also shows that the higher means of Y-BLBs when co-incubating H. pylori $\mathrm{J99}$ and C. albicans ATCC 90028 were achieved when co-cultures were incubated at $40{ }^{\circ} \mathrm{C}$ for $48 \mathrm{~h}$. This same pattern was similar for all the possible combinations of co-cultures (data not shown). This assay was completed in triplicate. 


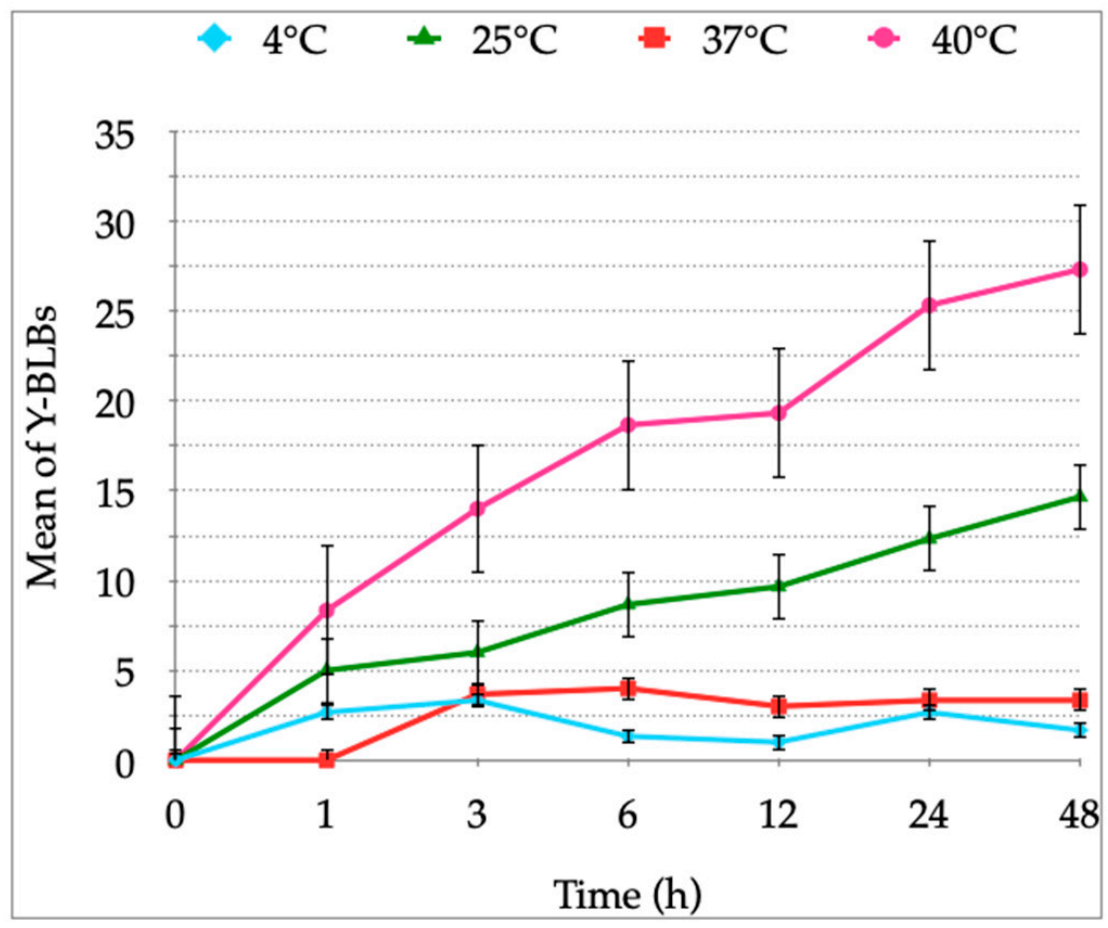

Figure 5. Means of yeasts harboring bacteria-like bodies (Y-BLBs) obtained in H. pylori J99 and C. albicans ATCC 90028 co-cultures incubated for up to $48 \mathrm{~h}$ at $4{ }^{\circ} \mathrm{C}, 25{ }^{\circ} \mathrm{C}, 37^{\circ} \mathrm{C}$ or $40{ }^{\circ} \mathrm{C}$ in Brucella broth supplemented with $5 \%$ fetal bovine serum. After calculating the Y-BLBs means for all combinations of $H$. pylori and Candida co-cultures, similar patterns were observed. Results are expressed as mean $\pm \mathrm{SD}$.

After determining that the differences in percentages of Y-BLBs depended on the bacterial strain and temperature (Figure 4), data were analyzed to ascertain if the endosymbiotic relationship also depended on the yeast strain used in the co-cultures. Based on the information provided in Figure 5, it was concluded that the larger percentages of Y-BLBs were present at $48 \mathrm{~h}$ of co-culturing at $40^{\circ} \mathrm{C}$. Data obtained in that particular incubation time were considered in order to analyze in which bacterium-yeast combination the higher Y-BLBs were obtained. The co-cultures, including the H. pylori J99 strain, showed the higher Y-BLBs means when co-incubated with any of the yeast strains assayed in the present work. (Figure 6). After analyzing if the symbiotic relationship also depended on the yeast strain, no significant difference was found to sustain this possibility (Table S1).

\subsection{Confirmation, by FISH, That BLBs Correspond to Intra-Yeast H. pylori}

FISH results confirmed that BLBs moving within the vacuoles of yeast cells revealed by the wet mounts are H. pylori cells. This conclusion is based on the red fluorescence emission emitted by the H. pylori-specific fluorescent probe that hybridized with the bacterial DNA within the yeast (Figure 7). Besides intra-yeast $H$. pylori detected by FISH, no other corpuscles were detected within yeast cells. 


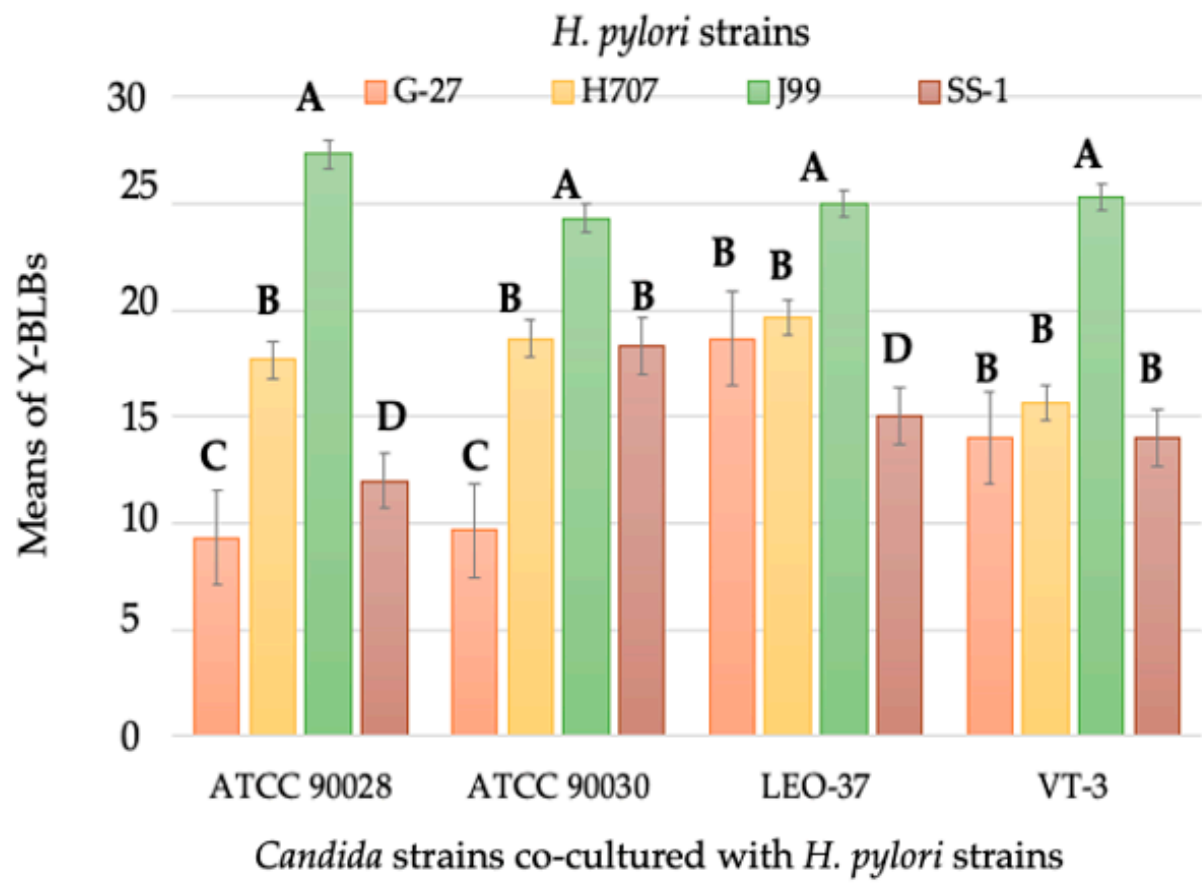

Figure 6. Means of yeasts harboring bacteria-like bodies (Y-BLBs) in H. pylori and Candida co-cultures incubated at $40^{\circ} \mathrm{C}$ for $48 \mathrm{~h}$. The higher means of Y-BLBs were observed when the H. pylori J99 strain was co-incubated with any of the four yeast strains assayed. Results are expressed as mean \pm SD. Means with different letters are significantly different $(p<0.05)$.
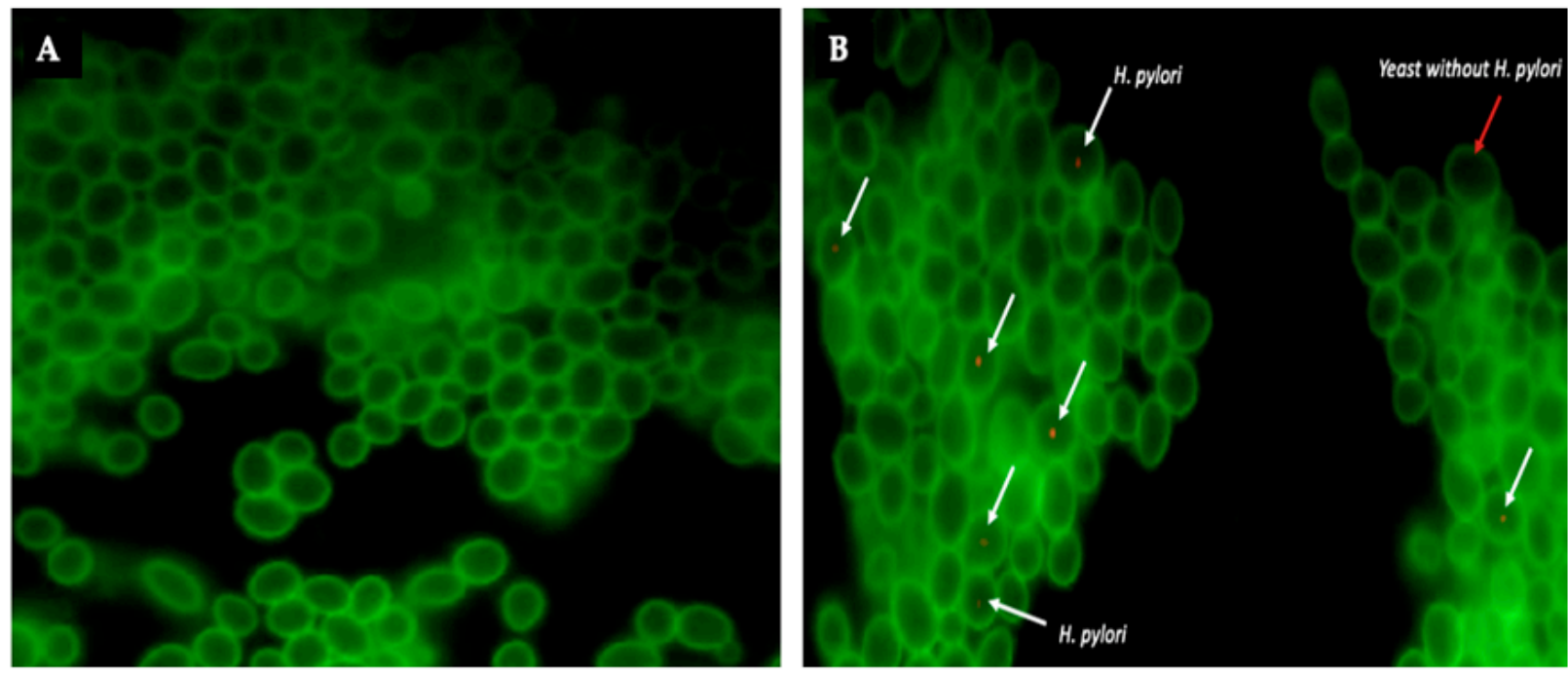

Figure 7. FISH identification of intra-yeast H. pylori. (A) Pure culture of C. glabrata ATCC 90030, (B) H. pylori J99-C. glabrata ATCC 90030 co-culture after hybridization to detect H. pylori using the Hpy 5'-CACACCTGACTGACTATCCCG-3' probe labeled with Cy3 (white arrows). Red arrow indicates a yeast cell lacking bacteria-like bodies. Green fluorescence corresponds to the ConA-FITC fluorochrome bind to chitin of the yeast cell wall.

3.4. Amplification of the H. pylori $16 S$ rRNA Gene from Total DNA Extracted from Yeast Cells Previously Co-Cultured with the Bacterium

To support the results obtained by FISH, an assay was performed to amplify by PCR the rRNA $16 S$ gene of $H$. pylori from total yeast DNA in which mobile BLBs were observed. All samples of yeast DNA in which the presence of BLBs was previously observed showed, in agarose gels, the presence of the amplicon of the expected size for the above-mentioned H. pylori gen (Figure 8). The same amplicon was also present in DNA extracted from pure 
H. pylori and absent in the DNA extracted from pure yeast (Figure 8). The presence of the H. pylori $16 S$ rRNA gene was detected in all yeasts isolated from co-cultures in which Y-BLBs were observed, and H. pylori was identified by the FISH technique.
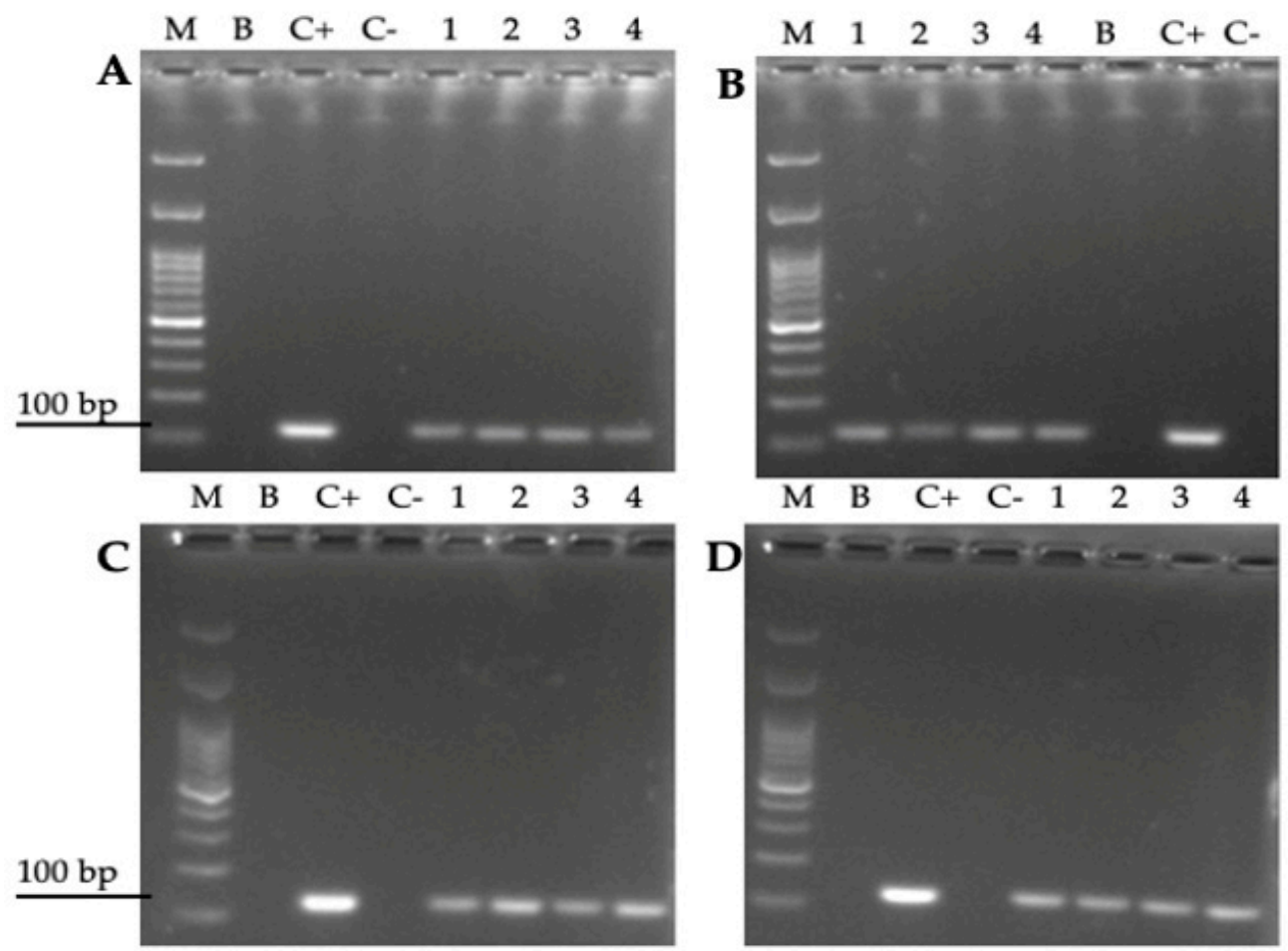

Figure 8. Agarose gel (2\%) showing amplicons obtained after PCR amplification of the H. pylori $16 S$ $r R N A$ gene from total DNA extracted from yeast cells after co-incubating bacterial and yeast cells for $24 \mathrm{~h}$ at $\left(\right.$ A) $4{ }^{\circ} \mathrm{C}$, (B) $25^{\circ} \mathrm{C}$, (C) $37^{\circ} \mathrm{C}$ or (D) $40^{\circ} \mathrm{C}$. M: molecular weight marker, B: blank (master mix, primers, PCR grade water), C-: negative control (pure C. albicans ATCC 90028 DNA), C+: positive control (pure H. pylori SS-1 DNA), lane 1: H. pylori J99-C. albicans ATCC 90028 co-culture, lane 2: H. pylori J99-C. glabrata ATCC 90030 co-culture, lane 3: H. pylori J99-C. albicans VT-3, lane 4: H. pylori J99-C. glabrata LEO-37.

\subsection{Cell Viability Assays}

After confirmation that BLBs corresponded to intra-yeast H. pylori using FISH and PCR techniques, the viability of yeast and bacterial cells was evaluated using the LIVE/DEAD BacLight Bacterial Viability kit in order to confirm that the movements of BLBs previously observed in the wet mounts prepared from the co-cultures corresponded to viable $H$. pylori cells within viable yeast cells. The green fluorescence present inside the vacuole of yeasts, caused by the SYTO 9 of the kit, demonstrates the viability of the intra-yeast bacteria (Figure 9). 


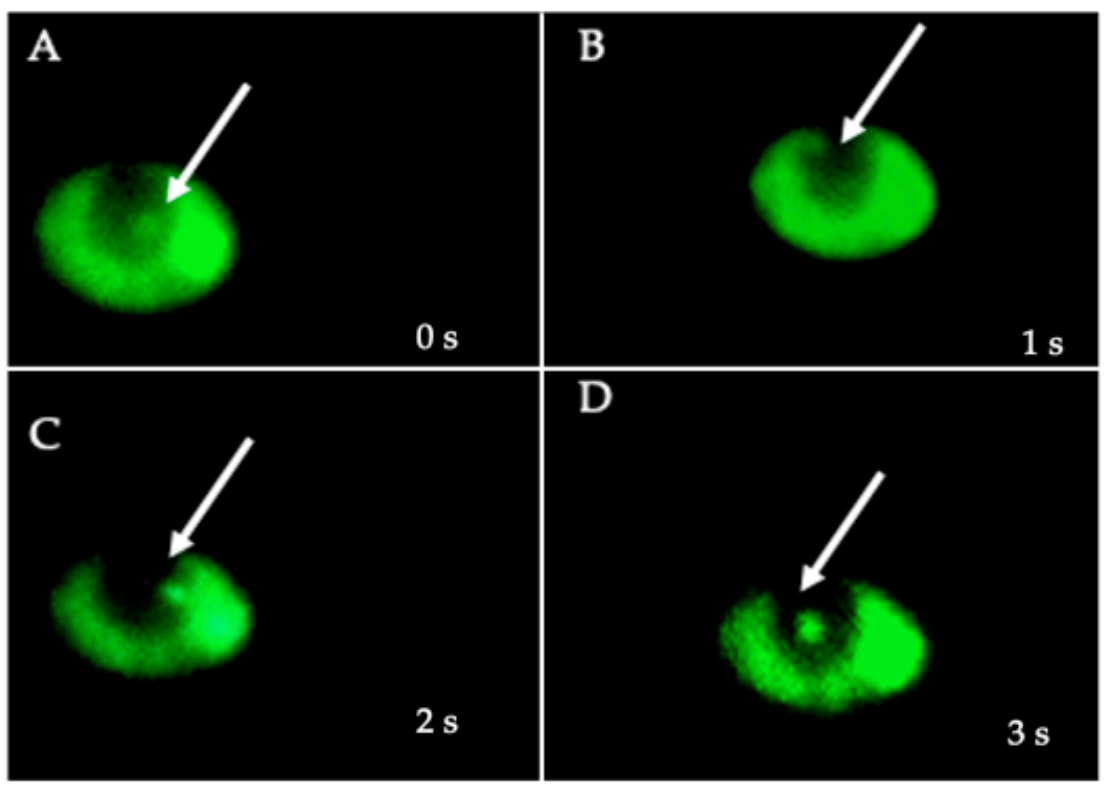

Figure 9. Viability assay micrographs, obtained at $1 \mathrm{~s}$ intervals $((\mathbf{A})$ time $0 \mathrm{~s},(\mathbf{B})$ time $1 \mathrm{~s},(\mathbf{C})$ time $2 \mathrm{~s}$, (D) time $3 \mathrm{~s}$ ) a viable (green fluorescence) $H$. pylori $\mathrm{J} 99$ cell within the vacuole of C. glabrata LEO-37 strain yeast cell. Images depict the change in the position of the H. pylori cell within the vacuole of the yeast cell caused by the movement of the bacterium.

\section{Discussion}

Temperature is an abiotic factor of importance for the diversity and the metabolism of organisms, including bacteria and fungi. Temperature directly affects microbial growth as well as fructification, sporulation, spore germination, motility and survival of fungi [51,52]. Therefore, each microorganism needs to remain within its appropriate range of temperature to survive. In fact, certain microorganisms can colonize environments whose temperature is below $0{ }^{\circ} \mathrm{C}$, while others colonize niches whose temperature is close to $100{ }^{\circ} \mathrm{C}$ [52]. During their life, microorganisms can be subjected to temperature fluctuations, changes to which they must rapidly adapt in order to survive.

H. pylori is considered a mesophilic bacterium whose growing temperature range is 35-37 ${ }^{\circ} \mathrm{C}$, and outside this range, it acquires a coccoid morphology corresponding to its VBNC condition $[26,53]$. This optimal temperature range is apparent when observing the growth curves reported in the present work for the four H. pylori strains assayed, which grew better at $37^{\circ} \mathrm{C}$ than at $4^{\circ} \mathrm{C}, 25^{\circ} \mathrm{C}$ or $40^{\circ} \mathrm{C}$. When incubated at $40^{\circ} \mathrm{C}$, the growth of the four $H$. pylori strains assayed was not significantly different to that shown at $37^{\circ} \mathrm{C}$, results supported by the literature indicating that its growth at $42{ }^{\circ} \mathrm{C}$ tends to be variable [53]. Therefore, although it was incubated at a temperature above its optimal range, it was not surprising that this bacterium grew at $40{ }^{\circ} \mathrm{C}$. It has been reported that when it finds itself outside its optimal temperature range, H. pylori will adopt its VBNC condition (coccoid morphology) [54]. This information, combined with our results, suggests that H. pylori is capable of surviving at $40^{\circ} \mathrm{C}$, but the exposure to this temperature is a stressing factor that induces the morphology change to the coccoid shape. This explains why our Gram-staining observations showed more $H$. pylori coccoid cells when incubation was completed at $40{ }^{\circ} \mathrm{C}$ as compared to incubation at $37^{\circ} \mathrm{C}$. On the contrary, no growth was observed when $H$. pylori was incubated at $25^{\circ} \mathrm{C}$ or $4{ }^{\circ} \mathrm{C}$. The statistical analysis of the optical densities of these two lower temperatures showed no significant in bacterial growth (measured assessing OD). These results are in accordance with those reported in the literature indicating that $H$. pylori may remain viable at these temperatures but does not replicate $[4,53,55]$.

Regarding yeasts of the Candida genus, they grow within a wider range of temperatures than H. pylori $\left(20-42^{\circ} \mathrm{C}\right)$ [56]. Therefore, it was expected that the yeast strains assayed in this work grew at $25^{\circ} \mathrm{C}, 37^{\circ} \mathrm{C}$ or $40^{\circ} \mathrm{C}$. On the other hand, the growth of yeast cells was 
significantly reduced when incubated at $4{ }^{\circ} \mathrm{C}$, a reasonable consequence of the slowing down of their metabolism, which affects their growth rate. Since yeast cells subjected to low temperatures $\left(10{ }^{\circ} \mathrm{C}\right.$ or less) activate an adaptative response which allows them to survive at temperatures close to freezing [57], it is possible to explain the growth, although significantly reduced, of Candida cells at $4{ }^{\circ} \mathrm{C}$ reported in this work.

The presence of BLBs within yeast cells previously co-incubated with $H$. pylori cells was observed in all the co-cultures combining pairs of each one of the four bacterial strains with each one of the four yeast strains. Numbers of Y-BLBs obtained in the cultures incubated at $37^{\circ} \mathrm{C}$, optimal for the growth of $\mathrm{H}$. pylori cells and yeast cells belonging to the genus Candida $[53,56]$, were used as a pattern to be compared with numbers of Y-BLBs obtained at the other temperatures assayed. The percentages of Y-BLBs at $37^{\circ} \mathrm{C}$ was $10-21 \%$, indicating that $H$. pylori harbors into a low percentage of yeast cells in the absence of an apparent stressing factor. This observation is in agreement with the results of another report of our laboratory in which we analyzed if $\mathrm{pH}$ variations, as a stressing factor, affected the harboring of $H$. pylori cells within yeast cells. The results of that report allowed concluding that although $\mathrm{H}$. pylori cells enter into yeast cells under optimal culture conditions, the percentages of Y-BLBs increased significantly at stressing acidic $\mathrm{pH}$ values $(\mathrm{pH} 3, \mathrm{pH} 4)$ [49]. When co-cultures were incubated at temperatures non-optimal for $H$. pylori, the percentages of Y-BLBs increased when co-cultures were incubated at $40{ }^{\circ} \mathrm{C}(46-57 \%)$ or $25^{\circ} \mathrm{C}(22-27 \%)$, but it was significantly reduced when subjected to $4{ }^{\circ} \mathrm{C}(8-11 \%)$. The presence of Y-BLBs in co-cultures incubated at temperatures of $25^{\circ} \mathrm{C}$ or $4{ }^{\circ} \mathrm{C}$ and the lack of growth of $\mathrm{H}$. pylori here reported at those temperatures confirms previous reports indicating that those are stressing temperatures for this bacterium $[5,53]$. Thus, it is possible to suggest that $H$. pylori harbors within yeast cells before its viability or its morphology are affected by a stressing temperature. There was a significant difference in the means of Y-BLBs when comparing co-cultures incubated at $4{ }^{\circ} \mathrm{C}$ or $25^{\circ} \mathrm{C}(p=0.002)$, being that the Y-BLBs were fewer at $4{ }^{\circ} \mathrm{C}$. A possible explanation for this difference could be that $H$. pylori loses motility and enters into the coccoid morphology at $4{ }^{\circ} \mathrm{C}$ faster than at temperatures close to $25^{\circ} \mathrm{C}$, permitting more Y-BLBs to occur at the higher of these two temperatures [58].

It has been reported that temperature also affects the morphogenesis of C. albicans, influencing its change from blastoconidia to pseudohypha or hypha, filamentous morphologies having adhesins that favor the adhesion of the yeast to cells of the host $[59,60]$. Although so far there are no reports describing hyphal receptors or adhesins involved in the internalization of $H$. pylori, we observed a large number of $H$. pylori cells adhered preferentially to hyphae of $C$. albicans. There are reports indicating that hyphae are structures rich in nutrients and in lipidic membranes plentiful in ergosterol, a sterol analogous to cholesterol, a lipid for which $H$. pylori has high affinity $[59,60]$, suggesting that this bacterium may have an affinity for ergosterol to use it in its metabolism. Nevertheless, more evidence is required to sustain this hypothesis. Finally, the behavior of the strains of each microorganism in the co-cultures was statistically analyzed, and it was concluded that the H. pylori and yeast cells endosymbiotic relationship was dependent on the bacterial strain and on the temperature inducing the harboring of $H$. pylori cells within yeast cells. When co-incubated with all yeast strains, the strain $H$. pylori J99 produced the largest percentages of Y-BLBs, independent of the yeast strain with which it was co-incubated. Although this strain showed larger percentages of Y-BLBs when co-incubated with C. albicans ATCC 90028, no significant differences were found when compared to the rest of the yeast strains. No significant differences were observed when the means of Y-BLBs resulting from co-culturing H. pylori J99 and C. albicans ATCC 90028 strains were compared with the Y-BLBs means resulting from the co-cultures of the H. pylori J99 strain with the other Candida strains.

On the other hand, co-cultures in which C. glabrata strains were used also showed high percentages of Y-BLBs; nevertheless, yeasts belonging to this fungal species do not form hyphae [61]. Therefore, the harboring of H. pylori cells within yeasts of this species may be facilitated by other characteristics of the yeast cells of this species. It has been 
described that $C$. glabrata possesses approximately 67 types of adhesins, components of their cell surface, which, among their functions, include biofilm formation, including mixed bacteria-yeast biofilms [62]. It has also been reported that yeasts belonging to the Candida genus co-aggregate with a number of bacteria, including Staphylococcus aureus, Enterococcus faecalis, Prevotella intermedia and Porphyromonas gingivalis [63]. Moreover, Ansorg and coworkers [44] reported the adherence of H. pylori to the surface of Candida spp. cells, particularly those not belonging to the species C. albicans, when not morphologically blastoconidia. Thus, to bring light to the endosymbiotic relationship between $H$. pylori and cells of yeasts belonging to the genus Candida, further in-depth research is required.

\section{Conclusions}

H. pylori showed a significant growth at $40{ }^{\circ} \mathrm{C}$, a temperature at which it also increased its harboring within yeast cells belonging to the Candida genus. Under the conditions of culturing used in this study, the endosymbiotic relationship between these two microorganisms is dependent on the H. pylori strain. It can also be concluded that $H$. pylori retains its viability when harbored within Candida spp. cells. Temperatures below the range considered as optimal for $H$. pylori, such as $4{ }^{\circ} \mathrm{C}$ or $25^{\circ} \mathrm{C}$, generate evident stress for this bacterium, but they did not favor the entry of bacteria into yeast cells because no significant percentages of Y-BLBs were detected at these temperatures. Therefore, $H$. pylori is less efficient at harboring within yeast cells at low temperatures, which rapidly affects its morphology or viability more than at high ones.

Supplementary Materials: The following are available online at https:/ / www.mdpi.com/article/10 $.3390 /$ biology $10090915 /$ s1, Figure S1: Gram staining of H. pylori 999 cultures incubated at $37^{\circ} \mathrm{C}(\mathrm{A})$ or $40{ }^{\circ} \mathrm{C}$ (B) showing the increased number of coccoid cells when incubated at $40{ }^{\circ} \mathrm{C}$.; Gram-staining of H. pylori H707-C. albicans VT-3 co-culture showing the co-aggregation of both microorganisms. Observe the preference of $H$. pylori cells for filamentous structures (pseudohyphae or hyphae). Figure S2: Gram-staining of H. pylori H707-C. albicans VT-3 co-culture showing the co-aggregation of both microorganisms. Observe the preference of $H$. pylori cells for filamentous structures (pseudohyphae and hyphae). Table S1: Analysis to evaluate if there were significant differences in Y-BLBs means when strains of $H$. pylori were incubated with Candida strains in $48 \mathrm{~h}$ co-cultures incubated at $40{ }^{\circ} \mathrm{C}$, Video S1: Movement of intra-yeast bacteria-like bodies (BLBs) observed in a wet mounting. (https:/ / youtu.be/Mj-KGUsdqUg, accessed on 10 August 2020)

Author Contributions: Conceptualization, K.S.-A. and A.G.-C.; methodology, K.S.-A., A.G.-C. and C.P.-S.; validation, K.S.-A., A.G.-C., C.P.-S., L.A.-A., C.T.S. and H.B.; formal analysis, K.S.-A., S.C.-S., L.A.-A., K.S. and H.B.; investigation, K.S.-A., C.P.-S., V.L.C. and A.G.-C.; resources, A.G.-C.; data curation, K.S.-A., K.S. and H.B.; writing-original draft preparation, K.S.-A., L.A.-A., S.C.-S., H.B.-H., C.T.S. and A.G.-C.; writing-review and editing, K.S.-A., C.P.-S., V.L.C., C.T.S. and A.G.-C.; visualization, K.S.-A., C.P.-S., V.L.C., C.T.S. and A.G.-C.; supervision, V.L.C., C.T.S. and A.G.-C.; project administration, C.P.-S. and A.G.-C.; funding acquisition, A.G.-C. All authors have read and agreed to the published version of the manuscript.

Funding: This work was supported by Grant VRID-Enlace 218.036.047-1.0, University of Concepcion, Concepcion, Chile.

Institutional Review Board Statement: Not applicable.

Informed Consent Statement: Not applicable.

Data Availability Statement: Not applicable.

Acknowledgments: The authors acknowledge the collaboration and support of Laboratorio Pasteur, Concepción-Chile.

Conflicts of Interest: The authors declare no conflict of interest.

\section{References}

1. Hathroubi, S.; Servetas, S.L.; Windham, I.; Merrell, D.S.; Ottemann, K.M. Helicobacter pylori Biofilm Formation and Its Potential Role in Pathogenesis. Microbiol. Mol. Biol. Rev. 2018, 82, 00001-00018. [CrossRef] [PubMed] 
2. Warren, J.R. Gastric Pathology Associated with Helicobacter pylori. Gastroenterol. Clin. N. Am. 2000, 29, 705-751. [CrossRef]

3. Talaei, R.; Souod, N.; Momtaz, H.; Dabiri, H. Milk of livestock as a possible transmission route of Helicobacter pylori infection. Gastroenterol. Hepatol. Bed Bench 2015, 8, S30-S36.

4. Quaglia, N.C.; Dambrosio, A.; Normanno, G.; Parisi, A.; Firinu, A.; Lorusso, V.; Celano, G.V. Survival of Helicobacter pylori in artificially contaminated ultrahigh temperature and pasteurized milk. Food Microbiol. 2007, 24, 296-300. [CrossRef] [PubMed]

5. Quaglia, N.C.; Dambrosio, A. Helicobacter pylori: A foodborne pathogen? World J. Gastroenterol. 2018, 24, 3472-3487. [CrossRef]

6. Siavoshi, F.; Sahraee, M.; Ebrahimi, H.; Sarrafnejad, A.; Saniee, P. Natural fruits, flowers, honey, and honeybees harbor Helicobacter pylori-positive yeasts. Helicobacter 2018, 23, e12471. [CrossRef]

7. Velázquez, M.; Feirtag, J.M. Helicobacter pylori: Characteristics, pathogenicity, detection methods and mode of transmission implicating foods and water. Int. J. Food Microbiol. 1999, 53, 95-104. [CrossRef]

8. Nilsson, H.-O.; Blom, J.; Abu Al-Soud, W.; Ljungh, A.A.; Andersen, L.P.; Wadström, T. Effect of Cold Starvation, Acid Stress, and Nutrients on Metabolic Activity of Helicobacter pylori. Appl. Environ. Microbiol. 2002, 68, 11-19. [CrossRef]

9. Ratkowsky, D.A.; Olley, J.; McMeekin, T.A.; Ball, A. Relationship between temperature and growth rate of bacterial cultures. J. Bacteriol. 1982, 149, 1-5. [CrossRef]

10. Huang, L.; Hwang, A.; Phillips, J. Effect of Temperature on Microbial Growth Rate-Mathematical Analysis: The Arrhenius and Eyring-Polanyi Connections. J. Food Sci. 2011, 76, E553-E560. [CrossRef]

11. Charpe, A.; Sedani, S.; Murumkar, R.; Bhad, R. Effect of Temperature on Microbial Growth in Food during Storage. Multilogic Sci. 2019, 8, 56-58.

12. Sjomina, O.; Pavlova, J.; Niv, Y.; Leja, M. Epidemiology of Helicobacter pylori infection. Helicobacter 2018, 23, e12514. [CrossRef] [PubMed]

13. Porras, C.; Nodora, J.; Sexton, R.; Ferreccio, C.; Jimenez, S.; Dominguez, R.L.; Cook, P.; Anderson, G.; Morgan, D.R.; Baker, L.H.; et al. Epidemiology of Helicobacter pylori infection in six Latin American countries (SWOG Trial S0701). Cancer Causes Control. 2012, 24, 209-215. [CrossRef] [PubMed]

14. O'Ryan, M.L.; Lucero, Y.; Rabello, M.; Mamani, N.; Salinas, A.M.; Peña, A.; Torres-Torreti, J.P.; Mejías, A.; Ramilo, O.; Suarez, N.; et al. Persistent and Transient Helicobacter pylori Infections in Early Childhood. Clin. Infect. Dis. 2015, 61, 211-218. [CrossRef]

15. Khoder, G.; Muhammad, J.S.; Mahmoud, I.; Soliman, S.S.M.; Burucoa, C. Prevalence of Helicobacter pylori and Its Associated Factors among Healthy Asymptomatic Residents in the United Arab Emirates. Pathogens 2019, 8, 44. [CrossRef] [PubMed]

16. Robinson, K.; Atherton, J.C. The Spectrum of Helicobacter-Mediated Diseases. Annu. Rev. Pathol. Mech. Dis. 2021, 16, 123-144. [CrossRef]

17. Alba, C.; Blanco, A.; Alarcón, T. Antibiotic resistance in Helicobacter pylori. Curr. Opin. Infect. Dis. 2017, 30, 489-497. [CrossRef]

18. Yang, T.; Li, H.; Chen, J.; Zeng, W.; Mao, J.; Zhang, Z.; Yang, J.; Yang, N.; Tu, M.; Zhang, J. Epidemiological study on antibiotic resistance among Helicobacter pylori in Taizhou district, Zhejiang, 2010-2013. Zhonghua Liu Xing Bing Xue Za Zhi 2014, 35, 704-707.

19. Dang, B.N.; Graham, D.Y. Helicobacter pylori infection and antibiotic resistance: A WHO high priority? Nat. Rev. Gastroenterol. Hepatol. 2017, 14, 383-384. [CrossRef] [PubMed]

20. Malfertheiner, P.; Megraud, F.; O’Morain, C.A.; Gisbert, J.P.; Kuipers, E.J.; Axon, A.T.; Bazzoli, F.; Gasbarrini, A.; Atherton, J.; Graham, D.Y.; et al. Management of Helicobacter pylori infection-the Maastricht V/Florence Consensus Report. Gut 2017, 66, 6-30. [CrossRef]

21. Warren, J.R.; Marshall, B. Unidentified curved bacilli on gastric epithelium in active chronic gastritis. Lancet 1983, 1, $1273-1275$.

22. Mladenova, I.; Durazzo, M. Transmission of Helicobacter pylori. Minerva Gastroenterol. Dietol. 2018, 64, 251-254. [CrossRef]

23. Cellini, L. Helicobacter pylori: A chameleon-like approach to life. World J. Gastroenterol. 2014, 20, 5575-5582. [CrossRef] [PubMed]

24. De Francesco, V.; Zullo, A.; Hassan, C.; Giorgio, F.; Rosania, R.; Ierardi, E. Mechanisms of Helicobacter pylori antibiotic resistance: An updated appraisal. World J. Gastrointest. Pathophysiol. 2011, 2, 35-41. [CrossRef] [PubMed]

25. Yonezawa, H.; Osaki, T.; Hanawa, T.; Kurata, S.; Ochiai, K.; Kamiya, S. Impact of Helicobacter pylori Biofilm Formation on Clarithromycin Susceptibility and Generation of Resistance Mutations. PLoS ONE 2013, 8, e73301. [CrossRef]

26. Azevedo, N.F.; Almeida, C.; Cerqueira, L.; Dias, S.; Keevil, C.W.; Vieira, M.J. Coccoid Form of Helicobacter pylori as a Morphological Manifestation of Cell Adaptation to the Environment. Appl. Environ. Microbiol. 2007, 73, 3423-3427. [CrossRef]

27. Chu, Y.-T.; Wang, Y.-H.; Wu, J.-J.; Lei, H.-Y. Invasion and Multiplication of Helicobacter pylori in Gastric Epithelial Cells and Implications for Antibiotic Resistance. Infect. Immun. 2010, 78, 4157-4165. [CrossRef]

28. Dubois, A.; Borén, T. Helicobacter pylori is invasive and it may be a facultative intracellular organism. Cell. Microbiol. 2007, 9 , 1108-1116. [CrossRef] [PubMed]

29. Liu, H.; Semino-Mora, C.; Dubois, A. Mechanism of H. pylori Intracellular Entry: An in vitro Study. Front. Cell. Infect. Microbiol. 2012, 2, 13. [CrossRef]

30. Lai, C.-H.; Huang, J.-C.; Cheng, H.-H.; Wu, M.-C.; Huang, M.-Z.; Hsu, H.-Y.; Chen, Y.-A.; Hsu, C.-Y.; Pan, Y.-J.; Chu, Y.-T.; et al. Helicobacter pylori cholesterol glucosylation modulates autophagy for increasing intracellular survival in macrophages. Cell. Microbiol. 2018, 20, e12947. [CrossRef]

31. Amieva, M.R.; Salama, N.R.; Tompkins, L.S.; Falkow, S. Helicobacter pylori enter and survive within multivesicular vacuoles of epithelial cells. Cell. Microbiol. 2002, 4, 677-690. [CrossRef]

32. Moreno-Mesonero, L.; Moreno, Y.; Alonso, J.L.; Ferrus, M.A. DVC-FISH and PMA-qPCR techniques to assess the survival of Helicobacter pylori inside Acanthamoeba castellanii. Res. Microbiol. 2016, 167, 29-34. [CrossRef] [PubMed] 
33. Moreno-Mesonero, L.; Moreno, Y.; Alonso, J.L.; Ferrus, M.A. Detection of viable Helicobacter pylori inside free-living amoebae in wastewater and drinking water samples from Eastern Spain. Environ. Microbiol. 2017, 19, 4103-4112. [CrossRef] [PubMed]

34. Moreno-Mesonero, L.; Hortelano, I.; Moreno, Y.; Ferrús, M.A. Evidence of viable Helicobacter pylori and other bacteria of public health interest associated with free-living amoebae in lettuce samples by next generation sequencing and other molecular techniques. Int. J. Food Microbiol. 2020, 318, 108477. [CrossRef]

35. Siavoshi, F.; Taghikhani, A.; Malekzadeh, R.; Sarrafnejad, A.; Kashanian, M.; Jamal, A.S.; Saniee, P.; Sadeghi, S.; Sharifi, A.H. The role of mother's oral and vaginal yeasts in transmission of Helicobacter pylori to neonates. Arch. Iran. Med. 2013, 16, $288-294$.

36. Salmanian, A.-H.; Siavoshi, F.; Akbari, F.; Afshari, A.; Malekzadeh, R. Yeast of the oral cavity is the reservoir of Heliobacter pylori. J. Oral Pathol. Med. 2008, 37, 324-328. [CrossRef]

37. Salmanian, A.-H.; Siavoshi, F.; Beyrami, Z.; Latifi-Navid, S.; Tavakolian, A.; Sadjadi, A. Foodborne Yeasts Serve as Reservoirs of Helicobacter pylori. J. Food Saf. 2011, 32, 152-160. [CrossRef]

38. Sánchez-Alonzo, K.; Parra-Sepúlveda, C.; Vergara, L.; Bernasconi, H.; García-Cancino, A. Detection of Helicobacter pylori in oral yeasts from students of a Chilean university. Rev. Assoc. Médica Bras. 2020, 66, 1509-1514. [CrossRef]

39. García-Ríos, E.; Morard, M.; Parts, L.; Liti, G.; Guillamón, J.M. The genetic architecture of low-temperature adaptation in the wine yeast Saccharomyces cerevisiae. BMC Genom. 2017, 18, 1-13. [CrossRef] [PubMed]

40. Takagi, Y.; Fukano, H.; Shimozato, K.; Tanaka, R.; Horii, T.; Kawamoto, F.; Kanbe, T. Genotypes of Candida albicans isolated from healthy individuals and their distribution in patients with oral candidiasis. J. Infect. Chemother. 2013, 19, 1072-1079. [CrossRef]

41. Angebault, C.; Djossou, F.; Abélanet, S.; Permal, E.; Ben Soltana, M.; Diancourt, L.; Bouchier, C.; Woerther, P.-L.; Catzeflis, F.; Andremont, A.; et al. Candida albicans Is Not Always the Preferential Yeast Colonizing Humans: A Study in Wayampi Amerindians. J. Infect. Dis. 2013, 208, 1705-1716. [CrossRef] [PubMed]

42. Bandara, H.M.H.N.; Panduwawala, C.P.; Samaranayake, L.P. Biodiversity of the human oral mycobiome in health and disease Oral Dis. 2019, 25, 363-371. [CrossRef] [PubMed]

43. Lemos-Carolino, M.; Madeira-Lopes, A.; van Uden, N. The temperature profile of the pathogenic yeast Candida albicans. J. Basic Microbiol. 1982, 22, 705-709. [CrossRef]

44. Ansorg, R.; Schmid, E.N. Adhesion of Helicobacter pylori to yeast cells. Zent. Bakteriol. 1998, 288, 501-508. [CrossRef]

45. Rai, P.; Chakraborty, S.B. Giant fungal gastric ulcer in an immunocompetent individual. Saudi J. Gastroenterol. Off. J. Saudi Gastroenterol. Assoc. 2012, 18, 282-284. [CrossRef]

46. Ince, A.T.; Kocaman, O.; Ismailova, M.; Tozlu, M.; Gücin, Z.; Iraz, M. A rare co-existence of Helicobacter pylori, Candida albicans and Candida kefyr in a giant gastric ulcer. Turk. J. Gastroenterol. 2014, 25, 435-436. [CrossRef]

47. Sánchez-Alonzo, K.; Belmar, L.; Parra-Sepúlveda, C.; Bernasconi, H.; Campos, V.L.; Smith, C.T.; Sáez, K.; García-Cancino, A. Antibiotics as a Stressing Factor Triggering the Harboring of Helicobacter pylori J99 within Candida albicans ATCC10231. Pathogens 2021, 10, 382. [CrossRef]

48. Sánchez-Alonzo, K.; Silva-Mieres, F.; Arellano-Arriagada, L.; Parra-Sepúlveda, C.; Bernasconi, H.; Smith, C.T.; Campos, V.L.; García-Cancino, A. Nutrient Deficiency Promotes the Entry of Helicobacter pylori Cells into Candida Yeast Cells. Biology 2021, 10, 426. [CrossRef]

49. Sánchez-Alonzo, K.; Parra-Sepúlveda, C.; Vega, S.; Bernasconi, H.; Campos, V.L.; Smith, C.T.; Sáez, K.; García-Cancino, A. In Vitro Incorporation of Helicobacter pylori into Candida albicans Caused by Acidic pH Stress. Pathogens 2020, 9, 489. [CrossRef]

50. Rüssmann, H.; Kempf, V.A.J.; Koletzko, S.; Heesemann, J.; Autenrieth, I.B. Comparison of Fluorescent in Situ Hybridization and Conventional Culturing for Detection of Helicobacter pylori in Gastric Biopsy Specimens. J. Clin. Microbiol. 2001, 39, 304-308. [CrossRef] [PubMed]

51. Li, H.; Huaiyang, Z.; Li, J.; Gao, H.; Li, P.; Zhou, H. The impact of temperature on microbial diversity and AOA activity in the Tengchong Geothermal Field, China. Sci. Rep. 2015, 5, 17056. [CrossRef] [PubMed]

52. Aragno, M. Responses of Microorganisms to Temperature. In Physiological Plant Ecology I: Responses to the Physical Environment; Lange, O.L., Nobel, P.S., Osmond, C.B., Ziegler, H., Eds.; Springer: Berlin/Heidelberg, Germany, 1981; pp. $339-369$.

53. Jiang, X.; Doyle, M.P. Effect of Environmental and Substrate Factors on Survival and Growth of Helicobacter pylori. J. Food Prot. 1998, 61, 929-933. [CrossRef] [PubMed]

54. Krzyżek, P.; Gościniak, G. Morphology of Helicobacter pylori as a result of peptidoglycan and cytoskeleton rearrangements. Gastroenterol. Rev. 2018, 13, 182-195. [CrossRef] [PubMed]

55. Kusters, J.G.; Gerrits, M.M.; van Strijp, J.A.G.; Vandenbroucke-Grauls, C.M. Coccoid forms of Helicobacter pylori are the morphologic manifestation of cell death. Infect. Immun. 1997, 65, 3672-3679. [CrossRef]

56. Nadeem, S.G.; Shafiq, A.; Hakim, S.T.; Anjum, Y.; Kazm, S.U. Effect of Growth Media, pH and Temperature on Yeast to Hyphal Transition in Candida albicans. Open J. Med Microbiol. 2013, 3, 185-192. [CrossRef]

57. Kandror, O.; Bretschneider, N.; Kreydin, E.; Cavalieri, D.; Goldberg, A.L. Yeast Adapt to Near-Freezing Temperatures by STRE/Msn2,4-Dependent Induction of Trehalose Synthesis and Certain Molecular Chaperones. Mol. Cell 2004, 13, 771-781. [CrossRef]

58. Pérez, M.C.P.; González, A.; Moreno, Y.; Ferrus, M.A. Helicobacter pylori growth pattern in reference media and extracts from selected minimally processed vegetables. Food Control. 2018, 86, 389-396. [CrossRef]

59. Sudbery, P.; Gow, N.; Berman, J. The distinct morphogenic states of Candida albicans. Trends Microbiol. 2004, 12, 317-324. [CrossRef] 
60. Sun, L.; Liao, K.; Wang, D. Effects of Magnolol and Honokiol on Adhesion, Yeast-Hyphal Transition, and Formation of Biofilm by Candida albicans. PLoS ONE 2015, 10, e0117695. [CrossRef]

61. Kumar, K.; Askari, F.; Sahu, M.S.; Kaur, R. Candida glabrata: A Lot More Than Meets the Eye. Microorganisms 2019, 7, 39. [CrossRef]

62. Rodrigues, M.E.; Gomes, F.; Rodrigues, C.F. Candida spp./Bacteria Mixed Biofilms. J. Fungi 2019, 6, 5. [CrossRef] [PubMed]

63. O'Donnell, L.E.; Millhouse, E.; Sherry, L.; Kean, R.; Malcolm, J.; Nile, C.J.; Ramage, G. Polymicrobial Candida biofilms: Friends and foe in the oral cavity. FEMS Yeast Res. 2015, 15, 15. [CrossRef] 